\title{
THE RELATIONSHIP BETWEEN CLASSROOM MANAGEMENT AND SENSE OF CLASSROOM COMMUNITY IN GRADUATE VIRTUAL CLASSROOMS
}

\author{
Dr. Ceyhun KAVRAYICI \\ ORCID: 0000-0002-8878-6102 \\ Faculty of Education \\ Anadolu University \\ Eskisehir, TURKEY
}

Received: 25/08/2020 Accepted: 08/10/2020

\begin{abstract}
Communication, motivation, time management, rules and behavior management, plan program activities and physical order are important in the management of virtual classrooms, as they are in the management of traditional classrooms. On the other hand, "sense of classroom community" in online learning environment is classified with connectedness and learning dimensions. Hence, both constructs are crucial for virtual classrooms, the aim of the study was to examine the relationship between classroom management and sense of classroom community. The research design of the study was correlational survey design in quantitative research paradigm. The population of the study consisted of 524 graduate students enrolled in distance education non-thesis master degree programs in one of the university in Central Anatolia Region of Turkey. The sample of the study consisted of 224 graduate students determined by using random sampling technique. The data were collected via Classroom Management Scale and Classroom Community Scale. The findings of the study revealed that leadership and instructional planning and implementation dimensions of classroom management predicted connectedness dimension of classroom community positively while leadership and instructional planning and implementation, organization and communication of classroom management predicted learning dimension of classroom community. The findings of the study provided useful information in designing virtual classrooms and increasing student satisfaction.
\end{abstract}

Keywords: Virtual classroom management, sense of classroom community, graduate education, distance education.

\section{INTRODUCTION}

Changes in the views of individuals towards the sustainability of learning based on the developments in science and technology cause changes in the views on education in virtual classrooms. Moreover, distance education is getting wider throughout the world and attracts attention of a great deal of students day by day. Hence, tenets for enhancing quality of distance education has been widely discussed in the literature. Since distance education is computer-oriented online environment, it may have some difficulties stemming from lack of interaction and feeling of isolation that would cause student dropouts (Rovai, 2002a). Individuals who feel isolated in online learning environments are less interested in lessons (Rovai, 2002b). Community building should be highlighted in order to keep the students in the program and in the class since it is necessary collaborative learning atmosphere. According to DiPietro et al., (2008) classroom management is a key component in quality development of instruction during distance education and it helps to build community in online classrooms. On the other hand, in a holistic view of educational management and leadership the processes of teaching and leading are related to connectedness, collaboration, community and commitment (Beattie, 2002). Hence, in order to increase effectiveness in online learning environments, it is thought that it is important to manage virtual classrooms for the purposes and to create a sense of community in classrooms. 


\section{LITERATURE REVIEW}

\section{Classroom Management}

Classrooms are educational settings where students and instructors work together in order to reach educational goals. Effective management of goal achievement process is crucial in educational systems. Hence, managing classrooms and creating effective learning environment is at the core of educational outcomes. Classrooms include diversity of events and complexities that reveal challenges for classroom management (Wolff, Jarodzka, \& Boshuizen, 2020). They are multidimensional learning environments that require numerous different skills and point of views in the process of management. Classroom management used to be conceptualized as management of student misbehavior and discipline of the classroom. However, building effective learning environment requires something more than systematic method of managing misbehavior and keeping students under control (Allen, 2010). Some of the scholars who consider the concepts such as; managing classrooms or classroom management refer to activities that involve organizing, planning and running the classroom. It requires undertaking specific actions influenced by self-efficacy (Slater \& Main, 2020). Thus, classroom management can be conceptualized as actions taken by the teachers in order to establish the environment, which aims to enhance students' social and moral growth and enables students' engagement in meaningful academic learning (Evertson \& Weinstein, 2006, p. 4). Accordingly, it is the sum of the actions behaving like an orchestra leader in order to build community and support learning environment (Evertson \& Harris 1999, p.60). Teachers, considered as, effective managers in the classroom perform management styles that match students' characteristics and classroom activities with previously-set instructional goals. (Emmer \& Stough, 2001).

Technologies that have an impact on classroom management could also have an impact on educator collaboration and relationship development with students (Cho, Mansfield, \& Claughton, 2020). A virtual classroom is an online classroom that enables students and teachers participants to interact with each other, communicate with one another (Iftakhar, 2016). As it is in physical classrooms, virtual classrooms include pedagogical interaction between teachers and students (Oparaji, Igbokwe \& Ugwude, 2020). They are the places that offer learning and teaching opportunities beyond the limitations of physically existed classes (Hsu, et. al., 1999). It is not difficult to state that virtual classrooms offer opportunities to facilitate active learning environments. Not only do virtual classroom environments provide material to learners, but they also offer live, interactive learning environments. Teachers in online learning environments can control their learning and teaching processes as they do in traditional classrooms (Yang \& Liu, 2007). Virtual classroom management refers some of the tasks as it does in managing traditional classrooms. Moreover, communication, motivation, time management, rules and behavior management, instructional planning and organizational order are also important in the management of virtual classrooms, as they are in the management of traditional classrooms (Polat, 2016).

\section{Sense of Classroom Community}

The sense of community can be defined as feelings that individuals belong to each other or to the group and it is a common belief that posits their needs would be met when they are committed to be together (McMillan \& Chavis, 1986). Sense of community maintains a sense of emotional connection, identity, belonging and wellbeing. Individuals with a sense of community have connections to goals and others and feel reinforced. They are better adjusted to common outcomes. Strong sense of community provides a place in which individuals can easily express their identities and enables acting as a buffer against threats (Rovai \& Wighting, 2005). If individuals had a high level of community feeling, they would feel more supported, feel more compatible with their situation, and can start targeting more than their own limited goals (Fisher et al., 2002). Besides, strong community feeling can increase sense of cooperation, satisfaction, well-being and warm relationship development (Bacete, Marande, \& Mikami, 2019). There needs to be community feeling within virtual learning environment that contributes common sense of vision during the course (Blaine, 2019). Moreover, classroom community is associated with student motivation and student engagement fostering classroom culture (Xudong \& Li, 2020). It is also remarked that the sense of community in online education environments ensures that the participants remain in the lessons, provide information flow in the point of owning common goals among students, and supports cooperation among the members (Wellman, 
1999). Sense of community is closely related to learning (Kosnik \& Beck, 2009) and Cross (1998) states that strong sense of community and desirable learning outcomes are correlated with each other. Rovai and Ponton (2005) found that there is positive relationship between student learning and sense of community in online learning environment. Studies indicate that interdependence and trust between individuals, shared beliefs, expectations and connectedness are among the main components of community feeling (Fisher et al., 2002; Wellman, 1999). Students who are geographically and physically far from each other, should be connected in virtual learning environments. According to Hagerty et al., (1993, p.293), "Connectedness occurs when a person is actively involved with another person, object, group, or environment, and that involvement promotes a sense of comfort, well-being, and anxiety-reduction". Sense of connectedness is also regarded as a critical factor in having sense of belonging, enhancing retention and decreasing turnover intention (Laux et al., 2016). Moreover, students who have sense of connectedness in online courses tend to show better academic performance (Gallien \& Oomen-Early, 2008) and tend to show more persistence (Sidman-Taveau \& Hoffman, 2019). Discussions on sense of classroom community can be gathered under two dimensions. According to Rovai (2002b), dimensions of the sense of classroom community includes connectedness and learning. While connectedness dimension includes concepts such as consistency, interindividual commitment and trust, learning dimension includes concepts such as meeting educational goals and expectations.

\section{Classroom Management and Classroom Community}

It is possible to state that meeting the educational goals and the educational expectations of individuals is related to the effective management of both face to face and virtual classrooms. Management and organization of classrooms as learning communities can be posited as powerful process for improving students' personal, social and academic knowledge in educational environments (Richmond \& McCroskey, 1992). It is also believed that classroom management is a process about interpersonal relationships--about providing a sense of caring, keeping connected with students and building community in the classroom (Weinstein, 2007). Building classroom community is something related with "internal control" of classroom management, where there is focus on constructing relationships with students and social learning. According to Watson and Battistich (2006), a sense of community has robust indications for student learning, which led to principals and teachers looking for variety of strategies for classroom management. Hence, community development can be regarded as a strategy that can be used to manage classrooms (Wubbels, 2011). In terms of classroom management, different areas of skill and knowledge were described such as building supportive atmosphere, creating student-teacher and peer relationships, determining appropriate behavior standards and establishing caring and safety classroom community (Jones \& Jones, 2004). All the experts in educational settings should notice that classroom management requires building healthy student-teacher relationships, which generates classroom community (Scarlett, 2015, p.33). Moreover, Wubbels (2011) moves the claim one-step further by indicating that community development is among the aims of classroom management. He indicates that community feeling in the classroom is the result of well-managed classrooms.

Based on the literature about classroom management and classroom community, it is not difficult to claim that there are several theoretical implications and hints about the relationships of the two concepts. However, it is not easy to encounter variety of empirical and descriptive researches that examine the relationships between the two concepts. Therefore, this study aims to address the gap in the literature by examining the relationship between classroom management and sense of classroom community in virtual classrooms. In this context, answers of the following questions were sought for:

- Are the dimensions of virtual classroom management statistically significant predictors of connectedness dimension of classroom community?

- Are the dimensions of virtual classroom management statistically significant predictors of learning dimension of classroom community? 


\section{METHODOLOGY}

\section{Design and Procedure}

The research was designed as correlational survey design based on the quantitative research paradigm. The research design, which aims to determine and describe the relationship between two or more variables, tries to explain human behavior or predict possible outcomes, is defined as a correlational design (Fraenkel et al., 2012).

Having been approved by the ethical committee of the University, the required permissions was obtained in order to distribute the data collection instruments. After that author prepared data collection instruments in Google Forms which allowed attendees to respond directly online. Graduated students in the research sample were reached through the distance education information system, WhatsApp groups created within the scope of the courses and directed by advisors, and the data were collected from students who participated in the research voluntarily.

\section{Participants}

The population of the study consisted of 524 graduate students that were enrolled in distance education non-thesis master degree programs in one of the university in Central Anatolia Region of Turkey in 20182019 academic year. The sample of the study consisted of 224 graduate students determined by using random sampling technique. Random sampling is a sampling method "in which each and every member of the population has an equal and independent chance of being selected" (Fraenkel et al., 2012, p. 94). Descriptive statistics about the sample were presented in Table 1.

Table 1. Descriptive statistics of the sample

\begin{tabular}{llcc}
\hline Features & Variable & $\mathrm{f}$ & $\%$ \\
\hline \multirow{3}{*}{ Gender } & Female & 142 & 63.4 \\
Program & Male & 82 & 36.6 \\
& Educational Administration & 61 & 27,2 \\
& Mathematics Teacher Education & 28 & 12,5 \\
& Educational Technologies & 22 & 9,8 \\
& Character and Value Education & 66 & 29,5 \\
& Visual Communication Design & 18 & 8,0 \\
& Measurement and Data Analytics & 15 & 6,7 \\
Bachelor's degree & Program in Distance Education & 14 & 6,3 \\
& Faculty of Education & 198 & 54,4 \\
Occupation & Other & 166 & 45,6 \\
& Teacher & 132 & 58,9 \\
& Principal in School & 10 & 4,5 \\
Total & Vice-Principal in School & 28 & 12,5 \\
& Student/Unemployed & 2 &, 9 \\
& Other & 52 & 23,2 \\
& & 224 & 100 \\
\hline
\end{tabular}




\section{Data Collection Tools}

Classroom Management Scale: Classroom Management Scale developed by Polat (2016) includes 46 items. The factors of the scale are instructor leadership $(\alpha=.94)$, motivation $(\alpha=.92)$, classroom rules and behavior management $(\alpha=.77)$, management of communication $(\alpha=.90)$, planning and implementation of teaching $(\alpha=.82)$, classroom organization $(\alpha=.80)$ and time management $(\alpha=.88)$. The items of the 5 -likert type scale are rated from strongly disagree (1) to strongly agree (5). The total score that can be obtained from the scale can range from 46 to 230. Internal consistency coefficient of the scale was reported as $\alpha=.94$. Internal consistency coefficient for this study was found as $\alpha=89$. The scale explained $\% 65.07$ of total variance with 7 factors.

Classroom Community Scale: Classroom Community Scale was developed by Rovai (2002b). The original form of the scale includes 20 items and 2 factors. The scale adopted to Turkish context by Ozturk (2009). Having completed the adaptation process, the scale with 13 items and 2 factors revealed. The factors of the scale are connectedness $(\alpha=.94)$ and learning $(\alpha=.92)$. The items of the 5 -likert type scale are rated from strongly disagree (1) to strongly agree (5). The total score that can be obtained from the scale can range from 13 to 65 . Cronbach's alpha internal consistency coefficient value for the whole scale was .85. Internal consistency coefficient for this study was found as $\alpha=87$. The scale explained $\% 50.62$ of total variance with 2 factors.

\section{Data Analysis}

Distribution of the data was checked, before the necessary analyses were performed. In order to determine whether the data were normally distributed, skewness and kurtosis values were examined. Skewness values of all variables were between -.23 and .95 while kurtosis values were between -.22 and .86 which were in reasonable intervals. Arithmetic mean and standard deviation were calculated in order to determine classroom management perceptions and classroom community feeling of the participants. Stepwise regression analyses were run in order to investigate the predictor levels of independent variables. However, the assumptions of regression analysis were tested first. Mahalanobis test was applied in order to determine the outliers. Since the data of two of the participants were identified as outliers, they were removed from the data set before running the regression analyses. Since the correlation coefficients between variables were under .70, there was not singularity problem in the data. Moreover, possible collinearity among the potential predictor variables was checked by referring VIF and tolerance values. VIF value of the predictors for connectedness dependent variable was 1.552 and the tolerance value was .644 as well. VIF values of predictors for learning dependent variable were ranged from 1.704 to 2.038 . Tolerance values for the same predictors were ranged from .491 to .587 . VIF and tolerance values in this study were acceptable since the literature recommends that VIF value should be under 10 and the tolerance value should be above .01 (Cohen et al. 2003). Last, Durbin-Watson values were calculated for each regression analysis in order to check autocorrelation. For the first regression analysis, Durbin-Watson value was 1.646 and 1.521 for the second one. Durbin-Watson values were between the acceptable interval of 1 and 3, which is recommended in the literature (Field, 2009, p.224). Hence, it was proved that there wasn't autocorrelation in the residuals.

\section{Findings}

In order to determine whether classroom management factors are statistically significant predictors of classroom community factors, stepwise regression analysis was used in the study. However, Pearson correlation coefficient was employed in order to test the strengths of relationship between predictors and dependent variables before performing regression analyses. Correlation coefficients were displayed in table 2 . As seen in Table 2 there were statistically significant and positive relationships between classroom community factors (connectedness and learning) and most of the classroom management factors such as; leadership $(\mathrm{r}=.418$ and $\mathrm{r}=.617, \mathrm{p}<.001)$, motivation $(\mathrm{r}=.357$ and $\mathrm{r}=.565, \mathrm{p}<.001)$, rules and behavior management $(\mathrm{r}$ $=.394$ and $\mathrm{r}=.566, \mathrm{p}<.001)$, communication $(\mathrm{r}=.283$ and $\mathrm{r}=.449, \mathrm{p}<.001)$, instructional planning and implementation $(\mathrm{r}=.388$ and $\mathrm{r}=.624, \mathrm{p}<.001)$ and organization $(\mathrm{r}=.241$ and $\mathrm{r}=.430, \mathrm{p}<.001)$. However, there were not statistically significant relationships between classroom community factors and 
time management factor of classroom management. Hence, time management variable was not included in stepwise regression analyses. The results of the analyses, which were performed with the remaining six correlated variables reveled two regression models for connectedness dimension and four regression models for learning dimension of classroom community.

Table 2. Relationships Between Classroom Management and Classroom Community Factors

\begin{tabular}{|c|c|c|c|c|c|c|c|c|c|}
\hline & 1 & 2 & 3 & 4 & 5 & 6 & 7 & 8 & 9 \\
\hline Leadership & - & & & & & & & & \\
\hline Motivation &, $702^{* *}$ & - & & & & & & & \\
\hline $\begin{array}{l}\text { Rules and Behavior } \\
\text { Management }\end{array}$ &, $726^{* *}$ &, $672^{* *}$ & - & & & & & & \\
\hline Communication &, $632 * *$ &, $444^{* *}$ &, $577^{* *}$ & - & & & & & \\
\hline $\begin{array}{l}\text { Instructional Planning } \\
\text { and Implementation }\end{array}$ &, $635^{* *}$ &, $590^{* *}$ &, $597^{* *}$ &, $369^{* *}$ & - & & & & \\
\hline Organization &, $325^{* *}$ &, $464^{* *}$ &, $372^{* *}$ & 093 &, $513^{* *}$ & - & & & \\
\hline Time Management & ,003 & ,040 &,- 052 & 092 & 071 & ,085 & - & & \\
\hline Connectedness & $418^{* *}$ &, $357^{* *}$ &, $394^{* *}$ &, $283^{* *}$ & $388^{* *}$ &, $241 * *$ &,- 036 & - & \\
\hline Learning &, $617^{* *}$ &, $565^{* *}$ &, $566^{* *}$ &, $449 * *$ &, $624^{* *}$ &, $430 * *$ &,- 003 &, $560 * *$ & - \\
\hline
\end{tabular}

$* * p<.001$

Having completed correlation analysis, stepwise regressions were employed. Table 3 indicates results of stepwise regression analysis for prediction of connectedness factor of classroom community. As seen in table 3, first model of the stepwise regression analysis included leadership. According to the first model, leadership in virtual classrooms, predicted $17.4 \%$ of classroom community feeling in virtual classrooms $\left(\mathrm{R}^{2}=.174\right)$. In the second model instructional planning and implementation was entered. Instructional planning and implementation, as an additional variable, created $.03 \mathrm{R}^{2}$ change. More specifically, leadership variable solely explained $17.4 \%$ of the variation in predicting connectedness in virtual classrooms. Instructional planning and implementation variable explained 3\% additional variation. To sum up, aforementioned variables predicted connectedness positively and they explained $20.4 \%$ of the variation in connectedness scores.

Table 3. Results of Stepwise Regression Analysis for Prediction of Connectedness factor of Classroom Community

\begin{tabular}{lllllllllll}
\hline Model & & $\mathrm{B}$ & $\begin{array}{l}\text { Std. } \\
\text { Err. }\end{array}$ & $\beta$ & $\mathrm{t}$ & $\mathrm{p}$ & $\mathrm{R}^{2}$ & $\Delta \mathrm{R}^{2}$ & $\begin{array}{l}\mathrm{R}^{2} \\
\text { Change }\end{array}$ & $\mathrm{F}$ \\
\hline 1 & Leadership &, 316 &, 046 &, 418 & 6,849 &, 000 &, 174 &, 171 &, 174 & 46,910 \\
& Leadership &, 219 &, 057 &, 289 & 3,865 &, 000 & & & & \\
\hline & $\begin{array}{l}\text { Instructional } \\
\text { Planning and } \\
\text { Implementation }\end{array}$ &, 273 &, 095 &, 216 & 2,886 &, 004 &, 204 &, 197 &, 030 & 28,393 \\
\hline
\end{tabular}


Table 4 indicates results of stepwise regression analysis for prediction of learning factor of classroom community. As seen in table 4, first model of the stepwise regression analysis included instructional planning and implementation. According to first model, instructional planning and implementation in virtual classrooms, predicted 39\% of learning in virtual classrooms $\left(\mathrm{R}^{2}=.390\right)$. In the second model leadership was entered. Leadership, as an additional variable, created $.081 \mathrm{R}^{2}$ change. At the third step, organization variable was entered in the model. Organization variable created $.016 \mathrm{R}^{2}$ change as well. At the end communication variable was entered in the fourth model. Communication, as the last additional variable, created .013 $\mathrm{R}^{2}$ change. More specifically, instructional planning and implementation variable solely explained 39\% of the variation in predicting learning. Leadership variable explained $8.1 \%$ and organization variable explained \%1.6 additional variation while communication explained $\% 1.3$ additional variation. To sum up, aforementioned variables predicted classroom community feeling positively and they explained $50 \%$ of the variation in learning scores.

Table 4. Results of Stepwise Regression Analysis for Prediction of Learning factor of Classroom Community

\begin{tabular}{|c|c|c|c|c|c|c|c|c|c|c|}
\hline Model & & B & $\begin{array}{l}\text { Std. } \\
\text { Err. }\end{array}$ & $\beta$ & $\mathrm{t}$ & $\mathrm{p}$ & $\mathrm{R}^{2}$ & $\Delta \mathrm{R}^{2}$ & $\begin{array}{l}\mathrm{R}^{2} \\
\text { Change }\end{array}$ & $\mathrm{F}$ \\
\hline 1 & $\begin{array}{l}\text { Instructional } \\
\text { Planning and } \\
\text { Implementation }\end{array}$ & 777 & ,065 & ,624 & 11,907 & 000 & 390 & 387 & ,390 & 141,776 \\
\hline \multirow[t]{2}{*}{2} & $\begin{array}{l}\text { Instructional } \\
\text { Planning and } \\
\text { Implementation }\end{array}$ & ,485 & ,079 & 390 & 6,148 & 000 & 471 & ,466 & 081 & 98,427 \\
\hline & Leadership & 278 & 048 & ,369 & 5,831 & ,000 & & & & \\
\hline \multirow{3}{*}{3} & $\begin{array}{l}\text { Instructional } \\
\text { Planning and } \\
\text { Implementation }\end{array}$ & ,389 & ,086 & ,313 & 4,539 & ,000 & 487 & 480 & ,016 & 69,747 \\
\hline & Leadership & ,278 & ,047 & ,370 & 5,917 & ,000 & & & & \\
\hline & Organization & 190 & ,072 & 149 & 2,650 & ,009 & & & & \\
\hline \multirow{4}{*}{4} & $\begin{array}{l}\text { Instructional } \\
\text { Planning and } \\
\text { Implementation }\end{array}$ & 387 & ,085 & 311 & 4,561 & ,000 & ,500 & 491 & ,013 & 54,746 \\
\hline & Leadership & ,205 & ,056 & 273 & 3,657 & ,000 & & & & \\
\hline & Organization & ,214 & ,072 & ,168 & 2,983 & ,003 & & & & \\
\hline & Communication & 127 & ,054 & 146 & 2,341 &, 020 & & & & \\
\hline
\end{tabular}

\section{DISCUSSION}

The results of the study revealed that Leadership and Instructional Planning and Implementation were statistically significant predictors of connectedness dimension of classroom community. According to this result, Leadership and Instructional Planning and Implementation predicted sense of connectedness positively in virtual classrooms. Namely, when students perceive leadership that is more effective and more planned instruction in virtual classrooms, they would feel more connected to the online learning environment. Although there was a lack of research examining the relationships between connectedness and dimensions of classroom management, it is possible to discuss the findings based on the framework in the literature. Thereby, it is possible to say that this finding is consistent with the literature on classroom management and connectedness. Classroom management literature highlights the importance of planning 
an implementing the instruction by focusing on preventative role of classroom management. Classroom management prevents problems and keep students engaged in dynamic learning atmosphere (Evertson \& Emmer, 2008). The perspective of preventative management emphasizes that a great deal of classroom problems can be solved through effective teaching, good planning, relevant and interesting lessons. (Arends, 2012). According to McNeely et al., (2002) positive classroom management is positively associated with stronger school connectedness and one of the major threats in connectedness is poor classroom management (Blum, 2005). More specifically, well-planned teachers implementing appropriate teaching methods within proactive classroom management increase the connectedness (Monahan et al., 2010). Leadership, on the other hand, is something that can influence students' classroom community behavior either positively or negatively (Allison et al., 2001) and it can be regarded as a useful tool in transforming nature of the classroom (Bolkan et al., 2011). According to Bower et al., (2015), leadership roles build connectedness by encouraging students. Leadership as encouragement, improvement and transformation tool influence how students perceive their learning environment and their willingness to get involved in the learning environment (Yuen et al., 2012). Indeed leadership practices like weaving several different worlds together through interpersonal relationships and creating equitable governance opportunities, can be accepted as integrated framework that enable connectedness (Ospina \& Foldy, 2010).

The second finding of the study indicated that Instructional Planning and Implementation, Leadership, Organization and Communication are statistically significant predictors of learning dimension of classroom community. In the other words when students perceive high level of well-planned instruction and its implementation, high level of leadership, organization and communication in virtual classroom, they would learn much more in online learning environment. For instance, scheduling, planning and implementing of instruction in the classroom during online education enable students love the courses and acquire the needed educational outcomes (de la Varre et al., 2014). Teachers who plan convenient tasks and classroom activities and who have a background about instructional approaches and strategies are tend to build a learning atmosphere that assures student collaboration on learning tasks and minimizes behavioral problems (Arends, 2012). Since each instructional design model emphasizes planning (Lynch, 2002), it would be regarded as a step that should not be overlooked during the process of behavioral management (Arends, 2012). Moreover, align with the findings of this study, the literature suggests that leadership and learning in educational settings are considered as inseparable (Barth, 2001) and it is a multi-faceted and complex process, appears in both social and instructional roles in educational settings. It enables autonomous learning for students (Katyal \& Evers, 2004). Leadership is an influential, expansive and on-going process that have an effect on student engagement in schools. According to Frost (2008), teachers are leaders of learning in classrooms and teacher or classroom leadership includes instructional leadership (Katyal \& Evers, 2004). The concept of teacher leadership argues that the position of teachers is central in learning. Instruction and educational development involve leadership by teachers in classrooms. (York-Barr \& Duke, 2004). Taking this view, leadership is something about meaning and knowledge construction collectively and it is about learning (Harris, 2008). Hence, the results of the studies revealed that leadership is a factor to predict educational outcomes and enhances student innovation (Hoehl, 2008). According to findings of the researches by Leithwood and Jantzi $(1999 ; 2000)$, classroom management is an aspect of leadership that promotes student learning. There were also results indicating that teacher leadership is a way of developing self efficacy in relation to child learning (Katzenmeyer and Moller 2001). Besides; Vesely et al., (2007) found that leadership role and instructor modelling are vital in community building in virtual classrooms. The third variable of the second model that predicted learning in virtual classrooms was organization. This finding of the study is consistent with the literature indicating that organization of the classroom includes sustaining learning environments which support aims of academic instruction (Brophy, 1988). Instructors have the responsibility of organizing and designing e-learning environments to implement educational goals (Richardson, et al., 2012). Researches also revealed that well organized classrooms were better in instruction and student development (Cameron et al., 2005) and learning communities should include supportive and structured environment (Vesely et al., 2007). The last variable of the second model was communication in predicting learning in virtual learning environment. Literature suggest that teachers who construct community on learning, are supposed to focus on impressive communication in educational process and highlight affects of interactions on learning outcomes (Richmond \& McCroskey, 1992, p.22). The researches revealed that teachers who were lack of communication skills would have problems in leading 
students (Katyal \& Evers, 2004) since classroom management was correlated with problem solving and communication skills (Kavrayici, 2020). Moreover, coefficients in the study of Ni and Aust (2008) indicated that the effects of sense of classroom community and teacher verbal immediacy on learning and satisfaction were positive. Rovai (2003) also found that open, precise, friendly and collaborative communicator styles in virtual learning environment were positively related to learning and connectedness.

\section{CONCLUSION}

The results of the study revealed that leadership, motivation, rules and behavior management, communication, instructional planning and implementation and organization dimensions of classroom management were positively correlated with connectedness and learning dimensions of classroom community. However, only leadership and instructional planning and implementation dimensions of classroom management predicted connectedness dimension of classroom community positively while four dimensions (leadership and instructional planning and implementation, organization and communication) of classroom management predicted learning dimension of classroom community. As a practical implication, instructors and educational designers may need to rethink about designing virtual classrooms and educational programs to incorporate factors of classroom management and approaches to develop a sense of community. By doing so it would be possible to enhance student satisfaction when taking online courses. Instructors are supposed to find strategies to help students feel more comfortable and strongly connected with the instructor and with each other to make learning activities more meaningful. Instructors who manage the classroom effectively by leading, planning and purposefully organizing, thereby increasing sense of classroom community in terms of learning and connectedness (DiPietro et al., 2008 ), are likely to be successful in distance education (Rovai, 2002b).

\section{Limitations and Implications}

Although the study is the first one to examine the relationships between classroom management and sense of classroom community in virtual classrooms, it has limitations. A self-reported instrument was employed to gather the data about students' perceptions on classroom management and classroom community. There are always limitations in interpreting the constructs that the self-reported data collection instruments were measuring. Other respondent characteristics which were not checked in this study might have an effect upon the results of the study. Some variables like duration they spent in online courses, their technological opportunities could add more information for interpretation of the findings.

Future researches may be built on this study by more directly testing and investigating whether these factors are related with sense of classroom community in online courses of other samples (e.g., undergraduate students, college students and other countries). Studies designed in experimental or quasi-experimental designs would be helpful in confirming findings of this study in larger scale. Researches with qualitative or mixed method designs would also be helpful for us to get more detailed results on classroom management and sense classroom community in virtual classrooms.

Author's Note: Preliminary findings of the current study were presented as an abstract in International Open and Distance Learning Conference (IODL2019). 


\section{BIODATA and CONTACT ADDRESS of AUTHOR}

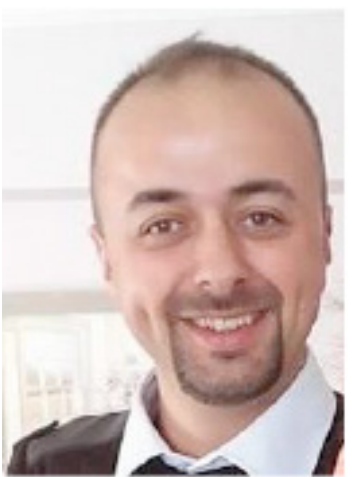

Ceyhun KAVRAYICI

Department of Educational Sciences, Faculty of Education

Address: Anadolu University, 26470, Eskisehir, Turkey

Phone: +90 2223350580

E-mail: ckavrayici@anadou.edu.tr, ceyhunkavrayici@gmail.com

\section{REFERENCES}

Allen, K. P. (2010). Classroom management, bullying, and teacher practices. Professional Educator, 34(1). Retrieved from https://files.eric.ed.gov/fulltext/EJ988197.pdf

Allison, B. J., Voss, R. S., \& Dryer, S. (2001). Student classroom and career success: The role of organizational citizenship behavior. Journal of Education for Business, 76, 282-288. https://doi. org/10.1080/08832320109599650

Arends, R. I. (2012). Learning to teach. McGraw-Hill Higher Education.

Bacete, F. J. G., Marande, G., \& Mikami, A. Y. (2019). Evaluation of a multi-component and multiagent intervention to improve classroom social relationships among early elementary school-age children. Journal of School Psychology, 77, 124-138. https://doi.org/10.1016/j.jsp.2019.09.001

Barth, R. S. (2001). Teacher leader. Phi Delta Kappan, 82, 443-449. https://doi. org/10.1177/003172170108200607

Beattie, M. (2002). Educational leadership: Modeling, mentoring, making and re-making a learning community. European Journal of Teacher Education, 25(2-3), 199-221. https://doi. org/10.1080/0261976022000036439

Blaine, A. M. (2019). Interaction and presence in the virtual classroom: An analysis of the perceptions of students and teachers in online and blended Advanced Placement courses. Computers \& Education, 132, 31-43. https://doi.org/10.1016/j.compedu.2019.01.004

Blum, R. W. (2005). A case for school connectedness. The Adolescent Learner, 62(7), 16-20. Retrieved from https://pdfs.semanticscholar.org/c147/f42f463c6ec513c388b2f9bf28196c33bf9b.pdf

Bolkan, S., Goodboy, A. K., \& Griffin, D. J. (2011). Teacher leadership and intellectual stimulation: Improving students' approaches to studying through intrinsic motivation. Communication Research Reports, 28(4), 337-346. https://doi.org/10.1080/08824096.2011.615958

Bower, J. M., Van Kraayenoord, C., \& Carroll, A. (2015). Building social connectedness in schools: Australian teachers' perspectives. International Journal of Educational Research, 70, 101-109. https://doi.org/10.1016/j.ijer.2015.02.004

Brophy, J. (1988). Educating teachers about managing classrooms and students. Teaching \& Teacher Education,4(1), 1-18. https://doi.org/10.1016/0742-051X(88)90020-0 
Cameron, C. E., Connor, C. M., \& Morrison, F. J. (2005). Effects of variation in teacher organization on classroom functioning. Journal of School Psychology, 43(1), 61-85. https://doi.org/10.1016/j. jsp.2004.12.002

Cho, V., Mansfield, K. C., \& Claughton, J. (2020). The past and future technology in classroom management and school discipline: A systematic review. Teaching and Teacher Education, 90, 1-11. https://doi. org/10.1016/j.tate.2020.103037

Cohen, J., Cohen, P., West, S. G. and Aiken, L. S. (2003). Applied multiple regression/correlation analysis for the behavioral sciences. Mahwah: Lawrence Erlbaum Associates

Cross, P. K. (1998). Why learning communities? Why now? About Campus, 3(3), 4-11. https://doi. org/10.1177/108648229800300303

de la Varre, C., Irvin, M. J., Jordan, A. W., Hannum, W. H., \& Farmer, T. W. (2014). Reasons for student dropout in an online course in a rural K-12 setting. Distance Education, 35(3), 324-344. https:// doi.org/10.1080/01587919.2015.955259

DiPietro, M., Ferdig, R. E., Black, E. W., \& Preston, M. (2008). Best practices in teaching K-12 online: Lessons learned from Michigan Virtual School teachers. Journal of Interactive Online Learning, 9(3), 10. Retrieved from https://oaks.kent.edu/ldespubs/20

Emmer, E. T., \& Stough, L. M. (2001). Classroom management: A critical part of educational psychology, with implications for teacher education. Educational Psychologist, 36(2), 103-112. https://doi. org/10.1207/S15326985EP3602_5

Evertson, C. M., \& Emmer, E. T. (2008). Classroom management for elementary teachers (8th ed.). Boston: Allyn \& Bacon.

Evertson, C. M., \& Harris, A. H. (1999). Support for managing learning-centered classrooms: The classroom organization and management program. In H. J. Freiberg (Ed.), Beyond behaviorism: Changing the classroom management paradigm (pp. 59-74). Needham Heights, MA: Allyn and Bacon.

Evertson, C. M., \& Weinstein, C. S. (2006). Classroom management as a field of inquiry. In Evertson, C. M., \& Weinstein, C. S. (Eds.), Handbook of classroom management: Research, practice, and contemporary issues. Routledge, NY.

Field, A. (2009). Discovering statistics for SPSS. Washington, DC: Sage.

Fisher, A. T., Sonn, C. C., \& Bishop, B. J. (2002). Psychological sense of community: Research, applications, and implications. New York: Kluwer.

Fraenkel, J. R., Wallen, N. E., \& Hyun, H. H. (2012). How to design and evaluate research in education. New York: McGraw-Hill.

Frost, D. (2008). 'Teacher leadership': Values and voice. School Leadership and Management, 28(4), 337-352. https://doi.org/10.1080/13632430802292258

Gallien, T., \& Oomen-Early, J. (2008). Personalized versus collective instructor feedback in the online course room: Does type of feedback affect student satisfaction, academic performance and perceived connectedness with the instructor? International Journal on E-learning, 7(3), 463-476. Retrieved from https://www.learntechlib.org/primary/p/23582/

Hagerty, B. M. K., Lynch-Sauer, J., Patusky, K. L., \& Bouwsema, M. (1993). An emerging theory of human relatedness. Journal of Nursing Scholarship, 25(4), 291-296. https://doi. org/10.1111/j.1547-5069.1993.tb00262.x

Harris, A. (2003). Teacher leadership as distributed leadership: heresy, fantasy or possibility?. School Leadership \& Management, 23(3), 313-324. https://doi.org/10.1080/1363243032000112801

Harris, A. (2008). Distributed leadership: According to the evidence. Journal of Educational Administration, 46(2), 172-188. https://doi.org/10.1108/09578230810863253 
Harrison, J. L. (2013). The effects of instructor transformational leadership and verbal immediacy on learner autonomy and creativity in online contexts. [Doctoral dissertation, Regent University]. Retrieved from ProQuest Dissertations \& Theses Global. (UMI No. 3570899)

Hoehl, S. E. (2008). The relationship between transformational leadership and student educational outcomes as moderated by verbal and nonverbal immediacy. [Doctoral dissertation, Regent University]. Retrieved from ProQuest Dissertations \& Theses Global. (UMI No. 3309288)

Hsu, S., Marques, O., Hamza, M. K., \& Alhalabi, B. (1999). How To Design a Virtual Classroom: 10 Easy Steps To Follow!. T.H.E. Journal, 27(2), 96-104. http://citeseerx.ist.psu.edu/viewdoc/ download?doi=10.1.1.555.1973\&rep=rep1\&type =pdf

Iftakhar, S. (2016). Google classroom: what works and how. Journal of Education and Social Sciences, 3(1), 12-18. Retrieved from http://jesoc.com/wp-content/uploads/2016/03/KC3_35.pdf

Iverson, A. M. (2003).Building competence in classroom management and discipline. Upper Saddle River, NJ: Merrill/Prentice-Hall.

Jones, V., \& Jones, L. (2004). Comprehensive classroom management: Creating communities of support and solving problems (7th ed). Boston: Allyn \& Bacon.

Katyal, K. R., \& Evers, C. W. (2004). Teacher leadership and autonomous student learning: Adjusting to the new realities. International Journal of Educational Research, 41(4-5), 367-382. https://doi. org/10.1016/j.ijer.2005.08.007

Katzenmeyer, M. \& Moller, G. (2001) Awakening the sleeping giant: Helping teachers develop as leaders. Thousand Oaks, CA: Corwin Press.

Kavrayici, C. (2020). Communication Skills and Classroom Management Competency: The Mediating Role of Problem-Solving Skills. Journal of Teacher Education and Educators, 9(1), 125-137. Retrieved from: https://files.eric.ed.gov/fulltext/EJ1254681.pdf

Kosnik, C., \& Beck, C. (2009). Priorities in teacher education: The 7 key elements of preservice preparation. London: Routledge.

Laux, D., Luse, A., \& Mennecke, B. E. (2016). Collaboration, connectedness, and community: An examination of the factors influencing student persistence in virtual communities. Computers in Human Behavior, 57, 452-464. https://doi.org/10.1016/j.chb.2015.12.046

Leithwood, K., \& Jantzi, D. (1999). The relative effects of principal and teacher sources of leadership on student engagement with school. Educational Administration Quarterly, 35(Suppl.), 679-706. https://doi.org/10.1177/0013161X99355002

Leithwood, K., \& Jantzi, D. (2000). Principals and teacher leadership effects: A replication. School Leadership and Management, 20 (4), 415-434. https://doi.org/10.1080/713696963

Little, G. D., \& Sanders, S. L. (1989). Classroom community: A prerequisite for communication. Foreign Language Annals, 22(3), 277-281. https://doi.org/10.1111/j.1944-9720.1989.tb02747.x

McMillan, D. W., \& Chavis, D. M. (1986). Sense of community: a definition and theory. Journal of Community Psychology, 14(1), 6-23. https://doi.org/10.1002/1520-6629(198601)14:1<6::AIDJCOP2290140103>3.0.CO;2-I

McNeely, C. A., Nonnemaker, J. M., \& Blum, R. W. (2002). Promoting school connectedness: Evidence from the national longitudinal study of adolescent health. Journal of School Health, 72(4), 138146. https://doi.org/10.1111/j.1746-1561.2002.tb06533.

Monahan, K. C., Oesterle, S., \& Hawkins, J. D. (2010). Predictors and consequences of school connectedness: The case for prevention. The Prevention Researcher, 17(3), 3-7. Retrieved from https:/go.gale. $\mathrm{com} / \mathrm{ps} /$ anonymous?id=GALE\%7CA259750109\&sid=googleScholar\&v=2.1\&it=r\& linkaccess $=\mathrm{abs} \& \mathrm{issn}=10864385 \& \mathrm{p}=\mathrm{HRCA} \& \mathrm{sw}=\mathrm{w}$ 
Morand, D. A. (2001). The emotional intelligence of managers: Assessing the construct validity of a nonverbal measure of people skills. Journal of Business and Psychology, 16(1), 21-33. Retrieved from https://ink.springer.com/content/pdf/10.1023/A:1007831603825.pdf

Ni, S. F., \& Aust, R. (2008). Examining teacher verbal immediacy and sense of classroom community in online classes. International Journal on E-learning, 7(3), 477-498.

Oparaji, I. C., Igbokwe, I. C., \& Ugwude, A. (2020). Class management as predictor of students' academic achievement in public secondary schools in Awka South of Anambra State. International Journal of Applied Reseaarch, 6(6), 353-357. Retrieved from https://www.researchgate. net/profile/Innocent_Igbokwe/publication/342625681_Impact_Factor_52_IJAR_2020/ links/5efdb27e299bf18816fa58c0/Impact-Factor-52-IJAR-2020.pdf

Ospina, S., \& Foldy, E. (2010). Building bridges from the margins: The work of leadership in social change organizations. The Leadership Quarterly, 21(2), 292-307. https://doi.org/10.1016/j. leaqua.2010.01.008

Ozturk, O. (2009). Sinif toplulugu olceginin Turkce'ye uyarlanmasi: Gecerlik ve guvenirlik calismasi [Adaptation of the classroom community index: The validity and reliability study]. Hacettepe Universitesi Egitim Fakultesi Dergisi, 36, 193-202. Retrieved from https://dergipark.org.tr/en/ download/article-file/87502

Polat, H. (2016). Cevrimici ogrenme ortamlarinda sinif yonetiminin cesitli degiskenler acisindan incelenmesi [Investigating adoption of instructors to distance education environment] (Doctoral dissertation). Retrieved from YOK TEZ. (Order No. 445651)

Richardson, J. C., Arbaugh, J. B., Cleveland-Innes, M., Ice, P., Swan, K. P., \& Garrison, R. (2012). Using the community of inquiry framework to inform effective instructional design. In L. Moller and J. B. Huett (Eds.), The next generation of distance education: Unconstrained learning (pp. 97-125). New York, NY: Springer.

Richmond, V. P., \& McCroskey, J. C. (1992). Power in the classroom: Communication, control, and concern. Hillsdale, NJ: Lawrence Erlbaum Associates, Inc

Rovai, A. P. (2002a). Sense of community, perceived cognitive learning, and persistence in asynchronous learning networks. The Internet and Higher Education, 5(4), 319-332. https://doi.org/10.1016/ S1096-7516(02)00130-6

Rovai, A. P. (2002b). Development of an instrument to measure classroom community. The Internet and Higher Education, 5(3), 197-211. https://doi.org/10.1016/S1096-7516(02)00102-1

Rovai, A. P. (2003). The relationships of communicator style, personality-based learning style, and classroom community among online graduate students. The Internet and Higher Education, 6(4), 347-363. https://doi.org/10.1016/j.iheduc.2003.07.004

Rovai, A. P., \& Ponton, M. K. (2005). An examination of sense of classroom community and learning among African American and Caucasian graduate students. Journal of Asynchronous Learning Networks, 9(3), 77-92. Retrieved from https://olj.onlinelearningconsortium.org/index.php/olj/ article/view/1786/617

Rovai, A. P., \& Wighting, M. J. (2005). Feelings of alienation and community among higher education students in a virtual classroom. The Internet and Higher Education, 8(2), 97-110. https://doi. org/10.1016/j.iheduc.2005.03.001

Scarlett, W., G. (2015). The SAGE encyclopedia of classroom management. Thousand Oaks, California: SAGE Publications.

Sidman-Taveau, R., \& Hoffman, M. (2019). Making change for equity: An inquiry-based professional learning initiative. Community College Journal of Research and Practice, 43(2), 122-145. https:// doi.org/10.1080/10668926.2018.1424665 
Slater, E. V., \& Main, S. (2020). A measure of classroom management: validation of a pre-service teacher self-efficacy scale. Journal of Education for Teaching, 1-15. https://doi.org/10.1080/02607476.2 020.1770579

Vesely, P., Bloom, L., \& Sherlock, J. (2007). Key elements of building online community: Comparing faculty and student perceptions. MERLOT Journal of Online Learning and Teaching, 3(3), 234246. Retrieved from https://jolt.merlot.org/vol3no3/vesely.pdf

Watson, M., \& Battistich, V. (2006). Building and sustaining caring communities. In C. M. Evertson \& C. S. Weinstein (Eds.), Handbook of classroom management: Research, practice and contemporary issues (pp. 253-279). Mahwah, NJ: Lawrence Erlbaum Associates.

Weinstein, C. S. (2007). Middle and secondary classroom management: Lessons from research and practice (3rd ed.). New York: McGraw-Hill.

Wellman, B. (1999). The network community: An introduction to networks in the global village. In Wellman, B. (Ed.) Networks in the Global Village, p.1-48. Boulder, CO: Westview Press.

Wolff, C. E., Jarodzka, H., \& Boshuizen, H. P. (2020). Classroom Management Scripts: a Theoretical Model Contrasting Expert and Novice Teachers' Knowledge and Awareness of Classroom Events. Educational Psychology Review, 1-18. https://doi.org/10.1007/s10648-020-09542-0

Wubbels, T. (2011). An international perspective on classroom management: What should prospective teachers learn? Teaching Education, 22(2), 113-131 https://doi.org/10.1080/10476210.2011.5 67838

Xudong, Z., \& Li, J. (2020). Investigating 'collective individualism model of learning': From Chinese context of classroom culture. Educational Philosophy and Theory, 52(3), 270-283. https://doi.or $\mathrm{g} / 10.1080 / 00131857.2019 .1638762$

Yang, Y., YoonJung, C., Mathew, S., \& Worth, S. (2011). College student effort expenditure in online versus face-to-face courses: The roleof gender, teamlearning orientation, and sense of classroom community. Journal of Advanced Academics, 22(4), 619-638. https://doi.org/10.1177/1932202X11415003

Yang, Z., \& Liu, Q. (2007). Research and development of web-based virtual online classroom. Computers \& Education, 48(2), 171-184. https://doi.org/10.1016/j.compedu.2004.12.007

York-Barr, J., \& Duke, K. (2004). What do we know about teacher leadership? Findings from two decades of scholarship. Review of Educational Research, 74(3), 255-316. https://doi. org/10.3102/00346543074003255

Yuen, M., Lau, P. S., Lee, Q. A., Gysbers, N. C., Chan, R. M., Fong, R. W., Chung, Y., B. \& Shea, P. M. (2012). Factors influencing school connectedness: Chinese adolescents' perspectives. Asia Pacific Education Review, 13(1), 55-63. http://dx.doi.org/10.1007/s12564-011-9176-7 